\title{
The Impact of School Locale on Pupils' Competencies in Selected Subjects: Does It Matter More for Specific Regions in Ghana?
}

\author{
Maxwell Kwesi Nyatsikor, ${ }^{1}$ Winston Kwame Abroampa, ${ }^{2}$ \& Kweku Esia-Donkoh³
}

Abstract
This study examined the impact of rural and urban schools on pupils' competencies in the English language
and Mathematics tests. The sample comprised 16,481 Primary 3 and 14,495 Primary 6 pupils from 448 and
426 schools respectively. The schools were selected using the stratified random sampling technique and the
data analysed using a multilevel modelling technique. The study found statistically significant differences in
achievement between rural and urban school pupils at both the national and regional levels. Compared with
urban school children, rural school children on average scored 2 and 4 marks less in primary 3 and 6 English
language tests respectively. Similarly, rural school children on average earned 1 mark less in primary 3 and 6
mathematics tests. Rural school children in the Eastern Region were the most disadvantaged by scoring 6 and
8 marks less in the primary 3 and 6 English language tests respectively when compared with their urban peers.
The only exception was the Northern Region where the average achievements of rural school children were
higher than their urban peers. The findings suggest that it significantly mattered which part of the country a
child attends school. This runs counter to the nation's educational policies and the realisation of the United
Nation's Sustainable Development Goal 4 . Hence, to provide quality and inclusive education for all pupils,
resources for schools and communities should be equitably distributed and effectively utilised.
Keywords: School locality, Socioeconomic, Competency, Regions

\section{Introduction}

Numerous studies on school and pupils' achievement across different contexts have found significant differences between schools serving the more-advantaged urban and the less-advantaged rural localities (Çiftçi \& Cin, 2018; Bashir, Lockheed, Ninan \& Tan, 2018; Ministry of Education [MOE], 2018; United Nations Educational, Scientific and Cultural Organisation [UNESCO], 2018). Between countries, evidence from international examinations such as Trends in International Mathematics and Science Study [TIMSS] and Programme for International Student Assessment [PISA] show significant differences in the achievement of children from low- to middle-income countries and high-income countries (Mullis, Martin \& Loveless, 2016; Martin, Mullis, Foy \& Hooper, 2016; Meyer \& Benavot, 2013). These achievement gaps are linked to the existing disparities in the social, economic, and educational resources in the nations and schools (Bashir, et al.,

Full listing of authors and contacts can be found at the end of this article.
2018; Martin et al., 2016; Meyer \& Benavot, 2013; MOE, 2016b). Many studies suggest that the effects of the rural-urban dichotomy on academic achievement are evident from the onset of formal schooling (MOE, 2018; UNESCO, 2018; World Development Report, 2018; Hanson et al., 2011). The sustained interest in the achievement outcomes at the primary level of education is reinforced by the fact that the quality of learning at this stage is crucial to later learning proficiencies and life's opportunities (Fredriksen \& Kagia, 2013; UNESCO, 2018; Bashir et al., 2018; United Nations [UN], 2015). In the Ghanaian context, evidence from the assessment of early and primary grade-levels in national assessments shows statistically significant differences in children from rural and urban schools (MOE, 2014; MOE, 2016a). Consistently, preschool and primary-level children from rural schools underachieve in national examinations when compared with children from urban schools (MOE, 2016b; MOE, 2018). This study examines the unique impact of the location of schools in rural and urban areas on the achievement levels of Ghanaian primary school children in the national 
education assessment tests in Mathematics and English language.

\section{School location and pupils' academic achievement}

Studies and reports across different contexts have, for the most part, concluded that pupils from urban schools achieved higher grades than those from rural schools (Destin, Hanselman, Buontempo, Tipton, Yeager, 2019; MOE, 2016a; Bashir, et al., 2018; Bofah \& Hannula, 2015). Some studies have suggested the differences in the social-economic characteristics of children from rural and urban schools as the main driver of the existing achievement gaps (Ryan, Koczberski, Curry \& Germis, 2017; Broer, Bai \& Fonseca, 2019). Parents of rural school children are generally unable to provide the educational needs for their children because of poverty. This constraint negatively affects the academic potentials of the child as evidenced by prior studies (Bofah \& Hannula, 2017; Bofah \& Hannula, 2015). Thus, children from economically disadvantaged households are typically educationally disadvantaged right from the onset of their formal education (Bashir et al., 2018; Kim, Cho \& Kim, 2019; Organization for Economic Co-operation and Development [OECD], 2016). Moreover, available data from Ghana suggest that many of the rural dwelling parents are semi-literate, hence, unable to assist their children in school or academic-related tasks (Ghana Statistical Service [GSS], 2014). For instance, 33.1\% of the population who had never attended school live in rural areas in contrast to $14.2 \%$ in the urban areas (GSS, 2012).

Other studies have suggested that urban schools outperform their rural counterparts because they tend to have higher expectations and are more likely to have parents who participate in school activities (Adeyemi, Adediran \& Adewole, 2018; Prasertcharoensuk \& Tapkhwa, 2016). The achievement gaps between rural and urban schools have also been linked to the differences in the professional characteristics of teachers serving in rural and urban schools (Nyatsikor, Sosu, Mtika \& Robson, 2020; Hill, Charalambous \& Chin, 2019; Bhai \& Horoi, 2019). Urban schools are often staffed with teachers who are more experienced and possess higher academic and professional qualifications than teachers in rural schools (MOE, 2018; Bashir et al., 2018). Even though there is a plethora of research showing significant differences in achievement between urban and rural schools, in some cases no significant differences were found. For instance, Considine and Zappala (2002) found that geographical location does not significantly predict outcomes in school performance in Australia. This is because school children in rural Australia have access to an adequate number of educational facilities. Nonetheless, similar studies from equally developed nations, particularly the USA, reveal stark achievement differences between rural and urban communities (Cochran-Smith \& Zeichner, 2005; Owens, 2018; Reardon, 2011; Reardon et al., 2019). Though the focus on rural and urban school achievement has caught the attention of researchers and policymakers for decades, this current study extends prior studies by investigating the impact of school location on academic achievement in a methodologically different way. First, an estimation of the unique influence of school location on achievement was done, and secondly, the actual numbers of pupils who achieved or failed to achieve certain levels of competencies using the derived estimates attributed to school location were determined. To achieve this purpose, the following research questions were formulated to guide the study.

\section{Research Questions}

1. To what extent do the inequalities in rural and urban schools account for pupils' achievement in English language and mathematics?

2. How much of the variance in pupils' achievement can be attributed to schools in different localities of a geographical region?

\section{Context of the Study}

This study relied on the 2013 wave of the Ghana National Education Assessment [GNEA] data. The GNEA started in 2005 and it is held biennially by the RTI International and the USAID in collaboration with the Ghana Education Service. The purpose of the assessment is to assess primary 3 (in 2016 primary 4 pupils examined) and primary 6 pupils' competence in mathematics and the English language subjects (MOE, 2014; MOE, 2016a). The primary 3 (P3) and 6 (P6) pupils were assessed and scored over a 30-item and 40-item test respectively. Pupils' achievement was assessed at three levels but different cut-off points for the two grade-levels. For the P3 mathematics and English language tests, pupils who answered a maximum of 10 items correctly (i.e. below 35\%) performed "below minimum competency". Pupils who correctly answered a minimum of 11 and a maximum of 16 items (i.e. 35\% - 54\%) attained "minimum competency" while those who correctly answered at least 17 items or better (i.e. $\geq 55 \%$ ) were "competent". In the case of the P6 sample,

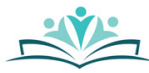


Table 1: Performance levels of $P 3$ and P6 pupils by subject and grade

\begin{tabular}{|c|c|c|c|c|c|c|c|c|c|c|}
\hline \multirow{4}{*}{$\begin{array}{l}\text { Competency } \\
\text { level }\end{array}$} & \multirow{2}{*}{\multicolumn{2}{|c|}{$\begin{array}{l}\text { Score } \\
\text { range } \\
\text { (marks) }\end{array}$}} & \multicolumn{8}{|c|}{ Subject and Percentage Score } \\
\hline & & & \multicolumn{4}{|l|}{$P 3$} & \multicolumn{4}{|l|}{ P6 } \\
\hline & \multirow[t]{2}{*}{ P3 } & \multirow[t]{2}{*}{ P6 } & \multicolumn{2}{|c|}{ English Language } & \multicolumn{2}{|c|}{ Mathematics } & \multicolumn{2}{|c|}{ English Language } & \multicolumn{2}{|c|}{ Mathematics } \\
\hline & & & Number & $\%$ & Number & $\%$ & Number & $\%$ & Number & $\%$ \\
\hline $\begin{array}{l}\text { Below } \\
\text { minimum } \\
\text { competency }\end{array}$ & $\begin{array}{l}0 \cdot \\
10\end{array}$ & 0.13 & 7,555 & $\begin{array}{c}41.9 \\
{[45.8]^{1}}\end{array}$ & 7,558 & $\begin{array}{c}42.9 \\
{[45.9]^{1}}\end{array}$ & 4,885 & $\begin{array}{c}31.3 \\
{[33.7]^{12}}\end{array}$ & 5,874 & $\begin{array}{c}39.1 \\
{[40.5]^{2}}\end{array}$ \\
\hline $\begin{array}{l}\text { Minimum } \\
\text { competency }\end{array}$ & $\begin{array}{l}11- \\
16 \\
\end{array}$ & $\begin{array}{l}14- \\
21\end{array}$ & 4,837 & $\begin{array}{c}29.7 \\
{[29.4]^{1}} \\
\end{array}$ & 5,680 & $\begin{array}{c}35.0 \\
{[34.4]^{1}} \\
\end{array}$ & 4,378 & $\begin{array}{c}29.7 \\
{[30.2]^{2}}\end{array}$ & 7,117 & $\begin{array}{c}50.0 \\
{[49.1]^{2}}\end{array}$ \\
\hline Competency & $\begin{array}{l}17- \\
30\end{array}$ & $\begin{array}{l}22- \\
40\end{array}$ & 4,089 & $\begin{array}{c}28.4 \\
{[24.8]^{1}}\end{array}$ & 3,243 & $\begin{array}{c}22.1 \\
{[19.7]^{1}}\end{array}$ & 5,232 & $\begin{array}{c}39.0 \\
{[36.1]^{2}}\end{array}$ & 1,504 & $\begin{array}{c}10.9 \\
{[10.4]^{2}}\end{array}$ \\
\hline \multicolumn{3}{|c|}{ Total } & 16,481 & 100 & 16,481 & $\begin{array}{c}10 \\
0\end{array}$ & 14,495 & 100 & 14,495 & 100 \\
\hline
\end{tabular}

${ }^{1}$ equivalent percentage performance distribution after excluding unclassified localities and class sizes less than 10.

Source: Ghana 2013 National Education Assessment Technical Report, p. x.

pupils who correctly answered up to 13 items (i.e. below 35\%) performed "below minimum competency". Pupils who had 14 up to 21 marks (i.e. 35\% - 54\%) attained "minimum competency" while those who correctly answered at least 22 items or better (i.e. $\geq 55 \%$ ) were "competent" in a subject (see Table 1 for performance distribution by subject and grade-levels).

The data in Table 2 show considerable differences in the achievement of rural and urban pupils in both subjects at the two grade-levels. The percentage of children from urban schools who were competent in both subjects for the two grade-levels was higher than those from rural schools. On the other hand, the percentage distributions of the performances below minimum competency were higher for pupils from the rural schools for both subjects and grade-levels. The percentage distributions of performance levels show significant connections between school locality and achievement. However, it is impossible to determine the unique effect of school location on the performance of pupils. This is because the influence of the location of schools on achievement is confounded by other factors including the characteristics of the pupils (e.g. age and gender), schools (e.g. type and class size), and districts (e.g. resource levels).

\section{Methodology \\ Design, Sample, and Sampling}

The study employed descriptive cross-sectional survey design. The study population comprised of primary school pupils from all the 10 regions in Ghana (currently there are 16 regions following the re-demarcation of 4 regions). The target population was the P3 and P6 pupils. The P3 sample size was 16,481 pupils [equivalent weighted sample $=93,008$ ] from 448 schools [equivalent weighted sample $=12,734]$. The P6 sample
Table 2: Performance levels of $\mathrm{P} 3$ and $\mathrm{P} 6$ pupils by school location

\begin{tabular}{|c|c|c|}
\hline \multirow[b]{3}{*}{ Competency level } & \multirow{2}{*}{\multicolumn{2}{|c|}{$\begin{array}{c}\text { Subject and Percentage Score } \\
\text { School Location }\end{array}$}} \\
\hline & & \\
\hline & Urban & Rural \\
\hline \multicolumn{3}{|l|}{ P3 English language (\%) } \\
\hline Below minimum competency & $29.6[29.2]^{1}$ & $49.0[52.0]^{1}$ \\
\hline Minimum competency & $26.7[26.6]^{1}$ & $30.6[30.4]^{1}$ \\
\hline Competency & $43.7[44.2]^{1}$ & $20.5[17.6]^{1}$ \\
\hline \multicolumn{3}{|l|}{ P3 Mathematics (\%) } \\
\hline Below minimum competency & $33.0[32.3]^{1}$ & $48.7[50.9]^{1}$ \\
\hline Minimum competency & $34.0[34.2]^{1}$ & $34.8[34.6]^{1}$ \\
\hline Competency & $33.0[33.5]^{1}$ & $16.5[14.5]^{1}$ \\
\hline \multicolumn{3}{|l|}{ P6 English language (\%) } \\
\hline Below minimum competency & $17.8[16.1]^{1}$ & $39.4[41.3]^{1}$ \\
\hline Minimum competency & $23.1[22.2]^{1}$ & $33.6[33.7]^{1}$ \\
\hline Competency & $59.2[61.7]^{1}$ & $27.1[25.0]^{1}$ \\
\hline \multicolumn{3}{|l|}{ P6 Mathematics (\%) } \\
\hline Below minimum competency & $27.7[25.5]^{1}$ & $46.1[47.0]^{1}$ \\
\hline Minimum competency & $54.5[55.7]^{1}$ & $46.6[46.2]^{1}$ \\
\hline Competency & $17.7[18.8]^{1}$ & $7.3[6.8]^{1}$ \\
\hline
\end{tabular}

comprised 14,495 pupils [equivalent weighted sample $=81,319$ ] from 426 [equivalent weighted sample $=12,393$ ]. The weighted school values are derived by dividing the total number of primary schools (which had a class size of at least ten pupils) in a region by the number of sampled schools from that region. For example, there were 1,821 primary 3 schools in the Eastern region out of which 55 participated in the assessment. The sample weight for schools in the Eastern region is therefore 33.11 (i.e. $1,821 \div 55=33.11$ ). Thus, each school that participated in the assessment from the 
Eastern region represented 33.11 schools. The weighted pupils' sample is derived by multiplying the weighted school value for each region by the number of pupils sampled from that region. For instance, the weighted sample $(57,312)$ for the P3 pupils from the Eastern region is derived by multiplying 33.11 by the total number of pupils $(1,731)$ sampled from the 55 schools in the region.

Schools were selected using stratified random sampling. Schools were stratified by regions and sorted by district, locality (urban or rural), school type (public or private) and enrolment size within the regions (MOE, 2014). Schools with less than 10 pupils in the class were excluded. Randomly, 55 schools were sampled with equal probability from each region except Ashanti and Northern regions where 54 schools each were selected because a school from each of these 2 regions was not in session at the time the test was administered. According to the MOE (2014), the reliability of the test was determined using SPSS Kuder-Richardson-20 (KR20) tests. Alpha values of 0.89 and 0.84 were achieved for the P6 mathematics and English language tests respectively. Alpha values of 0.82 and 0.84 were achieved for the P3 mathematics and English language tests respectively. The test questions were developed based on the specified topics in the national curricula. The English language test questions covered listening; reading comprehension; and usage (grammatical structure) domains. The mathematics test covered four domains namely: basic operations; numbers and numerals; measurement, shape and space; and collection and handling of data. The return rate for the answered scripts was $100 \%$ (MOE, 2014).

\section{Variables}

Independent variable - The independent variable for the study is 'school location' and was designated rural (0) or urban (1). In Ghana, urban localities are those with more than $60 \%$ of its residents engaged in non-agricultural activities in addition to having a minimum population size of 5,000. Otherwise, it is not urban (GSS, 2012). Urban schools have relatively better educationally-relevant resources than rural schools in terms of quantity and quality. There are more qualified teachers and better teaching and learning resources in urban than rural schools (MoE, 2014; MoE, 2018). The availability and quality of social amenities like potable water, functional electricity, , accessible roads, medical care, and internet connectivity are relatively better in urban communities when compared with rural commu- nities (Blampied, et al, 2018; United Nations International Cultural Educational Fund [UNICEF] and Centre for Democratic Development [CDD]-Ghana, 2019). Parents of rural school children are predominantly peasant farmers who live in poverty (GSS, 2012; Blampied et al., 2018). Levels of education, incomes and employment opportunities in the rural areas are significantly low and limited compared with those living in urban areas. As a result, rurality in Ghana connotes low socioeconomic status whereas urbanicity is associated with higher socioeconomic status (GSS, 2012; MoE, 2018; Blampied et al., 2018). Hence, in this study context, rural schools are used as a proxy for low SES while urban schools are used as a proxy for high SES. According to the GSS (2012) approximately $37.0 \%$ of children from primary grade 1 to 6 live in rural areas compared with $22.2 \%$ in urban areas. In this study, $77.9 \%$ of the P3 schools were located in rural communities compared with $22.1 \%$ in urban communities while $77.7 \%$ and $22.3 \%$ of the P6 schools were in rural and urban communities respectively.

Covariates - Five variables were controlled to account for their influence on pupils' achievement. These were pupils' gender (coded; male $=0$; female $=1$ ) and age, class size, school type (coded; public $=0$; private $=$ 1) and district type (coded; deprived = 1; non-deprived $=0$ ).

Dependent variables - The two dependent variables are mathematics and English language achievement scores for the primary 3 and 6 pupils who participated in the 2013 wave of the Ghana National Education Assessment test.

\section{Data Screening and Management}

Data were analysed using a multilevel modelling technique. Two exclusion criteria were applied to arrive at the final sample size. The first criterion was the exclusion of all schools not labelled as either rural or urban. The second criterion, which is based on statistical and methodological considerations was the exclusion of all schools which had less than 10 pupils in a class (see Hox, Moerbeek, van de Schoot, 2017; Heck \& Thomas, 2015). Applying these two criteria, data on 100 P3 schools (equivalent weighted sample $=2,843$ ) comprising 2,977 pupils (equivalent weighted sample $=80,004$ ) and 122 P6 schools (equivalent weighted sample $=3,468$ ) comprising 2,952 pupils (equivalent weighted sample $=79,990$ ) from the ten regions were excluded from the analysis. All the variable codes for the dichotomous variables were grand mean centred. 
Likewise, the continuous and dependent variables were grand mean centred. The grand mean centred achievement score for each pupil is the difference between a pupil's raw score and the grand mean achievement score derived from all pupils involved in the study. Grand mean centering ensured that the variances of the intercept and the slopes in the regression have a clear interpretation when all explanatory variables are equal to zero (Hox et al., 2017).

\section{Data Analysis Procedure}

The first stage of the analysis was to partition pupils' achievement as a null or intercept-only model to estimate the Intra-class Correlation Coefficient (ICC). The outcome of this partitioning helped to determine whether multilevel modelling was required to analyse the data (Hox et al., 2017; Heck \& Thomas, 2015). At stage two, the five covariates (pupils' gender, age, class size, school, and district types) were introduced into the model to quantify their influence on pupils' achievement. The third and final stage of the analysis was the introduction of the independent variable (school location) into the model to estimate its unique influence on pupils' achievement. From the estimates derived, the numbers of pupils who attained specific levels of proficiencies in both subjects on merit or as a result of the inequalities between rural and urban schools are determined. The second part of the analysis examined the unique influence of the location of schools on the achievement of pupils in each of the ten regions. achievement for the P3 pupils from rural schools was 11.2 and 11.6 while that for urban schools was 14.0 and 15.9 for Mathematics and English Language. The mean mathematics and English language achievement for the P6 pupils from rural schools was 14.3 and 16.8 while that for urban schools was 17.1 and 24.0 for Mathematics and English language. Preliminary analysis of the data using the t-test showed statistically significant $(p$-value $=0.000)$ mean differences in achievement between rural and urban schools for both subjects.

In Supplemental Table 1 [use link to view table], the fixed effects estimates show that the P3 pupils who attended rural schools on average, earned 2 marks ( $b$ $\left.=-2.085, \chi^{2}=16.8,-2 \mathrm{LL}=21, \mathrm{df}=6, \mathrm{p}=0.000\right)$ and 1 mark less $\left(b=-1.498, \chi^{2}=16.8,-2 L L=16, d f=6, p=\right.$ 0.000 ) in the English language and mathematics respectively when compared with those who attended urban schools. The unconditional models for the P3 sample revealed that a greater proportion of the achievement variances in the English language (54.8\%) and mathematics $(63.5 \%)$ remained unexplained by the number of variables investigated. School-level inequalities accounted for $29.7 \%$ and $28.4 \%$ of achievement differences in English language and mathematics respectively. District level differences also influenced achievement variances in the English language (15.5\%) and mathematics $(8.9 \%)$.

In Supplemental Table 2, the fixed effects estimates show that the P6 pupils who attended rural schools were predicted to have attained approximately 4 marks $\left(b=-3.654, \chi^{2}=16.8,-2 L L=35, d f=6, p=0.000\right)$

\section{Descriptive Analysis}

\section{Results}

The descriptive information about the school and pupil characteristics is presented in Table 3. The samples from public schools for both grade-levels were at least 5 times more than those from private schools. Similarly, the number of rural schools was more than thrice of urban schools. The mean class size for the P3 sample was bigger for urban schools (62.7) than the rural schools (47.2). The respective class sizes for the P6 urban and rural schools were 64.8 and 43.9. The average ages for the P3 pupils from the rural and urban schools were 10.9 and 10.4 respectively. As well, the average ages for the $\mathrm{P} 6$ pupils from the rural and urban schools were 13.8 and 13.3 respectively. The mean mathematics and English language
Table 3: Descriptive information about school and pupil characteristics

\begin{tabular}{|c|c|c|c|c|}
\hline \multicolumn{2}{|c|}{ Variables } & Total & \multicolumn{2}{|c|}{ Locality } \\
\hline \multicolumn{2}{|l|}{ P3 } & & Rural & Urban \\
\hline \multicolumn{2}{|l|}{ Sample size } & $16,481[93,008]^{1}$ & $73.0 \%$ & $27.0 \%$ \\
\hline \multirow[t]{2}{*}{ Gender } & Boys & 8692 & $52.3 \%$ & $51.6 \%$ \\
\hline & Girls & 7789 & $47.7 \%$ & $48.4 \%$ \\
\hline \multirow[t]{2}{*}{ No of Schools } & Public & 361 & $75.4 \%$ & $24.6 \%$ \\
\hline & Private & 87 & $59.0 \%$ & $41.0 \%$ \\
\hline \multicolumn{2}{|l|}{ Pupil Age ${ }^{2}$} & 10.8 & 10.9 & 10.4 \\
\hline \multicolumn{2}{|l|}{ Class size $^{2}$} & 51.8 & 47.2 & 62.7 \\
\hline \multicolumn{2}{|l|}{ Mathematics ${ }^{2}$} & 12.0 & 11.2 & 14.0 \\
\hline \multicolumn{2}{|c|}{ English language $^{2}$} & 12.7 & 11.6 & 15.9 \\
\hline \multicolumn{5}{|l|}{ P6 } \\
\hline \multicolumn{2}{|l|}{ Sample size } & $14,495[81,319]^{1}$ & $69.8(\%)$ & $30.2(\%)$ \\
\hline \multirow[t]{2}{*}{ Gender } & Boys & 7,431 & 52.3 & 48.9 \\
\hline & Girls & 7,064 & 47.7 & 51.1 \\
\hline \multirow[t]{2}{*}{ No of Schools } & Public & 351 & 72.4 & 27.6 \\
\hline & Private & 75 & 53.9 & 46.1 \\
\hline \multicolumn{2}{|l|}{ Pupil Age ${ }^{2}$} & 13.6 & 13.8 & 13.3 \\
\hline \multicolumn{2}{|l|}{ Class size $^{2}$} & 50.1 & 43.9 & 64.8 \\
\hline \multicolumn{2}{|l|}{ Mathematics $^{2}$} & 15.1 & 14.3 & 17.1 \\
\hline \multicolumn{2}{|c|}{ English language ${ }^{2}$} & 19.0 & 16.8 & 24.0 \\
\hline
\end{tabular}


and 1 mark less $\left(b=-1.401, \chi^{2}=16.8,2 L L=17, d f=6, p\right.$ $=0.000$ ) in the English language and mathematics tests respectively. The unconditional models for the $\mathrm{P} 6$ sample indicated that respectively $54.2 \%$ and $70.1 \%$ of the variances in achievement for English language and mathematics remained unexplained given the number of variables investigated. School-level differences accounted for $29.1 \%$ and $20.5 \%$ of the achievement variances in English language and mathematics respectively while district-level differences accounted for $16.7 \%$ and 9.4\% of achievement variances in English language and mathematics respectively.

The next stage of the analysis was to determine the number of pupils who attained or failed to attain specific levels of competency after accounting for the existing inequalities between rural and urban schools. As an example, the estimate derived for P3 English language achievement is used to calculate the number of pupils who attained specific levels of proficiency. From the results, 2 marks are added to the initial scores obtained by each pupil. As a result, pupils who initially scored 0 to 8 mark(s) would now earn between 2 and 10 marks; a performance below minimum competence (see Table 1). Pupils who initially scored 9 and 10 marks (i.e. below minimum competence) would now earn between 11 and 12 marks to attain "minimum competency". Next, we add 2 marks to the minimum mark (i.e. 11) for attaining minimum competency level to get 13 marks. This means all pupils who initially scored 11 to

Table 4: Competency levels of students by school location

\begin{tabular}{|l|l|l|l|l|l|}
\hline \multirow{4}{*}{ Subject/ competency level } & \multicolumn{3}{|l|}{ P3 } & P6 \\
\cline { 2 - 6 } & $\begin{array}{l}\text { Number } \\
\text { of pupils }\end{array}$ & $\%$ & $\begin{array}{l}\text { Number } \\
\text { of pupils }\end{array}$ & $\%$ \\
\hline \multirow{4}{*}{$\begin{array}{l}\text { English } \\
\text { language }\end{array}$} & Competent (due to inequalities) & 1,216 & 29.7 & 1,893 & 36.2 \\
\cline { 2 - 6 } & $\begin{array}{l}\text { Competent (inequalities accounted } \\
\text { for) }\end{array}$ & 2,873 & 70.3 & 3,339 & 63.8 \\
\cline { 2 - 6 } & $\begin{array}{l}\text { Minimum competency (due to } \\
\text { inequalities) }\end{array}$ & 3,060 & 63.3 & 3,088 & 70.5 \\
\cline { 2 - 6 } & $\begin{array}{l}\text { Minimum competency (inequalities } \\
\text { accounted for) }\end{array}$ & 1,777 & 36.7 & 1,290 & 29.5 \\
\cline { 2 - 6 } & $\begin{array}{l}\text { Below minimum competency (due to } \\
\text { inequalities) }\end{array}$ & 2,686 & 35.6 & 3,104 & 63.5 \\
\cline { 2 - 6 } & $\begin{array}{l}\text { Below minimum } \\
\text { competency(inequalities accounted } \\
\text { for) }\end{array}$ & 4,869 & 64.4 & 1,781 & 36.5 \\
\hline Mathematics & Competent (due to inequalities) & 987 & 30.4 & 626 & 41.6 \\
\cline { 2 - 6 } & $\begin{array}{l}\text { Competent (inequalities accounted } \\
\text { for) }\end{array}$ & 2,256 & 69.6 & 878 & 58.4 \\
\cline { 2 - 6 } & $\begin{array}{l}\text { Minimum competency (due to } \\
\text { inequalities) }\end{array}$ & 2,424 & 42.7 & 2,417 & 34.0 \\
\cline { 2 - 6 } & $\begin{array}{l}\text { Minimum competency (inequalities } \\
\text { accounted for) }\end{array}$ & 3,256 & 57.3 & 4,700 & 66.0 \\
\cline { 2 - 6 } & $\begin{array}{l}\text { Below minimum competency (due to } \\
\text { inequalities) }\end{array}$ & 1,339 & 17.7 & 1,203 & 20.5 \\
\cline { 2 - 6 } & $\begin{array}{l}\text { Below minimum competency } \\
\text { (inequalities accounted for) }\end{array}$ & 6,219 & 82.3 & 4,671 & 79.5 \\
\hline
\end{tabular}

13 marks were influenced by the existing inequalities between rural and urban schools. Those who scored 14 marks up to 16 marks attained minimum competency on merit. By the same analogy, all pupils who were competent but had between 17 up to 19 marks attained this level of achievement due to specific factors associated with the location of schools. Consequently, pupils who correctly answered a minimum of 20 out of the total 30 items in the test were those who achieved competency on merit after accounting for the impact of school location. The same procedure is used to estimate the number of pupils who attained or failed to attain specific competencies in the remaining subjects across both grade-levels as presented in Table 4 .

The existing inequalities in rural and urban schools had cascading effects on pupils' achievement at all levels of expected competencies in both subjects. Controlling for the inequalities in school localities, the results indicated that $2,873(70.3 \%)$ out of the 4,089 and $2,256(69.6 \%)$ out of the 3,243 pupils were meritoriously competent in P3 English language and mathematics respectively. The remaining 1,216 (29.7\%) and 987 (30.4\%) pupils were competent in P3 English language and mathematics respectively as gains derived from the location of the schools they attended. A total of 3,060 $(63.3 \%)$ of the 4,837 and $2,424(42.7 \%)$ of the 5,680 pupils attained minimum competency in P3 English language and mathematics respectively as a unique contribution from the location of the schools they attended. Respectively, 1,777 $(36.7 \%)$ and 3,256 (57.3\%) attained minimum competency in English language and mathematics on merit. A total of $4,869(64.4 \%)$ out of the 7,555 and $6,219(82.3 \%)$ out of the 7,558 pupils performed below minimum competency in P3 English language and mathematics tests on merit. The remaining 2,686 (35.6\%) and $1,339(17.7 \%)$ pupils performed below minimum competency in English language and mathematics tests respectively as a result of the deficiencies associated with the location of the schools they attended.

In respect of the P6 sample, $3,339(63.8 \%)$ out of the 5,232 and $878(58.4 \%)$ out of the 1,504 pupils were competent in English language and mathematics respectively on 
merit. The remaining 1,893 (36.2\%) and 626 (41.6\%) pupils achieved competency level in English language and mathematics respectively as a result of the advantages associated with the location of the schools they attended. Similarly, 3,088 (70.5\%) of the 4,378 and $2,417(34.0 \%)$ of the 7,117 pupils attained minimum competency in English language and mathematics respectively as an influence from the location of the schools they attended. Precisely, 1,290 (29.5\%) and $4,700(66.0 \%)$ pupils attained minimum competency in English language and mathematics on merit. Likewise, $1,781(36.5 \%)$ of the 4,885 and $4,671(79.5 \%)$ of the 5,874 P6 pupils performed below minimum competency in English language and mathematics respectively on merit. The remaining 3,104(63.5\%) and 1,203(20.5\%) of the P6 pupils performed below minimum competency in English language and mathematics respectively as a result of the deficits associated with the location of the schools they attended.

The second objective of the study was to determine the extent of the influence of school location on pupil's achievement in each of the regions. The results for both subjects and grade-levels are presented in Supplemental Tables 3-6. In Supplemental Table 3, the fixed effects estimates show that the impact of the rural schools on the P3 English language achievement for the Ashante $(b=-1.004)$, Upper West $(b=-1.484)$, Upper East $(b=$ $-1.968)$ and Western $(b=-.254)$ regions were less than the national average of 2 marks $(b=-2.085)$. The impact for Brong Ahafo $(b=-2.893)$, Eastern $(b=-6.477)$, Greater Accra $(b=-3.846)$, Northern $(b=3.038)$, Central $(b=-2.093)$, and Volta $(b=-2.355)$ regions were greater than the national average.

With respect to the P3 mathematics achievement, the fixed effects estimates in Supplemental Table 4 show that the Ashante ( $b=-.348)$, Volta $(b=-.968)$, Upper East $(b=-1.191)$ and Western $(b=-.481)$ regions had average values less than the national average of 1 mark $(b=-1.498)$. The remaining regions including Brong Ahafo ( $b=-2.259)$, Central $(b=-1.838)$, Eastern $(b=-5.486)$, Greater Accra ( $b=-2.908)$, Northern $(b=$ 2.219), and Upper East ( $b=-2.279$ ) had greater average values than that of the nation.

In respect of the P6 English language achievement the fixed effects estimates in Supplemental Table 5 show that the Ashante $(b=-1.376)$, Greater Accra $(b=$ -2.769), Northern $(b=.963)$, Upper East $(b=-2.970)$ and Western $(b=-.989)$ regions recorded less average impact than the national average of 4 marks $(b=-$ 3.654). The Central ( $b=-4.544)$, Eastern ( $b=-8.038)$ and Upper West $(b=-5.952)$, Brong Ahafo $(b=-4.474)$, and Volta $(b=-4.112)$ regions had greater mean values than the national average.

In Supplemental Table 6, the fixed effects estimates show that the estimates for Brong Ahafo $(b=-1.962)$, Central $(b=-2.321)$, Eastern $(b=-3.534)$, Upper West $(b=-2.335)$, Volta $(b=-2.623)$ were greater than the national average for P6 mathematics $(b=-1.401)$. The Ashante $(b=-.243)$, Greater Accra $(b=-.220)$, Northern $(b=.270)$ and Western $(b=.130)$ and Upper East $(b=-1.036)$ regions recorded lesser impact than the national average. Consistently across grade-levels and subjects, rural schools contributed negatively to pupils' achievement except for the Northern and Western (P6 mathematics achievement only) regions where the average achievement of rural schools was higher than urban schools. The Eastern and Western regions respectively came up as the regions with the most and least variances in achievement attributed to inequalities in rural and urban schools in Ghana. The implications of the results are discussed in the next section.

\section{Discussion of Results}

The unconditional models for both grade-levels and subjects indicated significant differences between school and district-level achievements. For the P3 sample, three of the covariates (i.e. pupils' age, district type, and school type) contributed significantly to achievement in both subjects (see Supplemental Table 1). The average achievement for relatively younger pupils was higher than older pupils while schools in deprived districts performed poorer compared with those in non-deprived districts. The types of schools pupils attend had the greatest impact on achievement. Children from private schools significantly outperformed those from public schools. Gender was significant only for mathematics achievement where boys did better than girls. There was no significant difference in achievement between genders with respect to the English language. The impact of class size on achievement in both subjects was not statistically significant.

For the P6 sample, all the five variables that were controlled made statistically significant impacts on pupils' achievement in both subjects. Children from private schools outperformed their counterparts from public schools, boys performed better than girls while relatively younger children outperformed the relatively older peers. Moreover, children from deprived schools performed poorer than those from non-deprived schools. Relatively smaller class sizes were not 
associated with improvement in achievement. The specific degrees of impact for each of the covariates are presented in Supplemental Table 2.

The advantages and disadvantages associated with the location of schools in specific communities produced corresponding gains and deficits in pupils' achievement. The results suggested that if conditions and educational resources in rural schools were improved by 1 unit, 2,686, and 1,339 more pupils would have at least attained minimum competency in the P3 English language and mathematics tests respectively. In same vein, $3,104(63.5 \%)$ and $1,203(20.5 \%)$ more of the P6 pupils would have at least attained minimum competency in English language and mathematics respectively had they attended schools in urban localities. The advantage of attending schools in certain parts of the country is evidenced by the 1,216(29.7\%) and $1,893(36.2 \%)$ pupils who were predicted to be competent in the P3 and P6 English language tests respectively solely by attending urban schools. Likewise, 987(30.4\%) and 626(41.6\%) pupils were competent in P3 and P6 mathematics solely by attending urban schools. The results suggest that pupils from rural schools achieved less than their peers from urban schools as a result of certain unfavourable conditions associated with attending schools in rural localities.

The advantages and disadvantages inherent with urban and rural schools have been explored in many contexts (MOE, 2016a; Bashir, et al. 2018; Çiftçi \& Cin, 2018; Cochran-Smith et al., 2012). Unanimously, these studies found that pupils from urban schools achieved higher grades than those from rural schools. Rural and urban communities serve as different psychological environments for children who share different resources, hazards, and opportunity structures. They may also have different life course options, and patterns of social interactions unique to the school catchment area (Bronfenbrenner, 2005; Tudge, Mokrova, Hatfield \& Karnik, 2009). As aptly observed by Rogošić and Baranović (2016), the differences in educational success can be attributed to different levels of existing social capital, which is produced in networks and connections of families that the school serves. A significant number of the rural schools in Ghana are disproportionately located in districts deprived of basic social amenities (e.g. electricity, internet), educational resources (e.g. less qualified teachers, teaching and learning materials), and economic opportunities to provide regular incomes for parents. Parents of rural school pupils are primarily peasant farmers and are characterised by high levels of poverty and illiteracy (GSS, 2015). These constraints significantly affect schools, parents and community-wide abilities to support the pro-academic activities of rural school children.

The current Covid-19 pandemic with its concomitant negative effects on education has further exacerbated the woes of the largely rural communities and schools in Ghana. Children in rural schools are unable to participate in the various remote digital learning initiatives rolled out by the Ghana Education Service. For the most part, internet connectivity is poor in rural communities and, where connectivity is possible parents are unable to afford data for internet use. Unlike urban communities, some rural communities do not have electricity to benefit from the government's strategy of teaching children via national television stations. The differing opportunities for children living in different parts of the country contribute to the widening of the achievement gaps (Nyatsikor et al., 2020; MOE, 2016b).

The second research question explored the impact of school location on the achievement of pupils within specific regions and the results reveal two important educational concerns. First, rural schools in the Northern and Western (for P6 mathematics achievement only) regions positively contributed to achievement in contrast with extant literature which suggests otherwise (Bashir et al., 2018; MOE, 2018). Like the rural localities, many of the urban localities in the Northern Region are equally deprived of basic social, economic and educational amenities that support effective teaching and learning (Blampied et al., 2018; MOE, 2018; UNICEF and CDD-Ghana, 2016). As a result, school locale becomes inconsequential since school children experience similar challenges and opportunities. Though this deprivation is prevalent in many parts of the country, available data suggest it is acute in the Northern region (MOE, 2016a; MOE, 2018, UNICEF and CDD-Ghana, 2016). Thus, the communities in which children attend schools serve as achievement opportunities and in the case of the Northern region, these opportunities are significantly similar for all schools regardless of their status as rural or urban.

In sharp contrast to the Northern region, there was a strikingly wide gap in achievement by pupils from rural and urban schools in the Eastern region, particularly for English language achievement. Consistently, rural children from the Eastern region were significantly disadvantaged. The persistent underachievement of rural schools (except for the Northern region) suggests 
inherent handicapping conditions associated with rural schools which create a "deficit model" for children's inability to receive superior education (Fan \& Chen, 2001; Hornby \& Lafaele, 2011). The significant gaps in pupils' achievement linked to school location may confirm the existence of extreme differences in the characteristics of the factors (e.g. socio-economic and educational resources) affecting school attainment in this part of the country. From the study results, it can be concluded that a major part of the generally low academic achievement among primary school children in Ghana is the uneven resources available to rural and urban schools as well as their socioeconomic backgrounds.

\section{Conclusion}

The study investigated the impact of school location on primary grades 3 and 6 pupils' academic achievement and found significant differences in achievement attributable to existing inequalities in rural and urban schools. Rural schools are deficient in many resources needed to facilitate effective teaching and learning leading to improved outcomes. Rural schoolchildren are characterised by high levels of poverty (low SES) relative to their urban counterparts (high SES). The cumulative impact of the disparities in social, economic and educational resources and opportunities for schools and communities is the achievement gaps between rural and urban school children.

The results for the Northern region call for a more comprehensive and robust investigation including the assessment of the threshold of indicators (e.g. economic, social, educational, and infrastructural resources) used to classify localities into rural and urban. The gaps in the achievement due to the location of schools in different parts of the country appear to suggest that children's present and possibly future educational fortunes depend on which part of the country they live in. This may be a testament to suggest that Ghana may not be achieving the goal of providing an equitable and inclusive education for all children as required by the country's educational policy and international goals (United Nations, 2015; MOE, 2015). With approximately $37.0 \%$ of primary school level children living in rural areas compared with $22.2 \%$ in urban areas (GSS, 2012), it presupposes that more children in rural communities may continue to record low achievements in selected school subjects if the disadvantages associated with attending rural schools are not addressed.

Ghana may therefore need to invest more resources per pupil to bridge the achievement gap between the rural and urban primary school children. It is imperative to suggest that any attempt aimed at closing the rural and urban achievement gaps must not gloss over the more fundamental preschool level. Many studies have found statistically significant connections between the quality of preschools and primary school achievement (Bakken, Brown \& Downing, 2017; OECD, 2017).

\section{Implications of the Study}

The findings from the study have enduring implications for all stakeholders in education. Some rural school children failed to be competent, attained minimum competency or performed below minimum competency in both subjects because of the inequalities between rural and urban schools. Data from the Ghana Statistical Service provides evidence of the significant differences between the socioeconomic and educational resources and opportunities for urban and rural dwellers. As developing country, majority of the population in the country are characterised by high levels of poverty. However, rural schools and children experience more disadvantages (e.g. educational and economic) and live in higher levels of poverty than their urban counterparts. It is incumbent on stakeholders, therefore, to ensure that the existing disparities between rural and urban parts of the country are bridged to close the achievement gaps between rural and urban school children.

\section{Limitations of the Study}

This study examined the influence of school location on primary level achievement in Mathematics and English language subjects and found significant achievement gaps between rural and urban schools. However, the unavailability of certain data to account for (e.g. pupils' prior achievement, teacher effect, school attendance history, household wealth, and parental support and community resources) may have over- or under-estimated the effects attributed to school location.

\section{Acknowledgment}

The lead author is grateful to the USAID and RTI International (the primary owners of the dataset) for the permission to use the Ghana National Education Assessment data for this research publication. All results from this research are the responsibility of the authors and do not implicate the custodians of the primary data in any way. 


\section{References}

Adeyemi, B.A., Adediran, V.O., \& Adewole, O.S. (2018). Influence of parental involvement, parental support and family education on pupils' adjustment in lower primary schools in Osun State. International Journal of Humanities Social Sciences and Education, 5(4), 67-75.

Bakken, L., Brown, N., \& Downing, B. (2017). Early childhood education: The long-term benefits. Journal of Research in Childhood Education, 31(2), 255-269.

Bashir, S., Lockheed, M., Ninan, E. \& Tan, J-P. (2018). $\underline{\text { Fac- }}$ ing forward schooling for learning in Africa. International Bank for Reconstruction and Development / The World Bank.

Bhai, M., \& Horoi, I. (2019). Teacher characteristics and academic achievement. Applied Economics, 51, 4781-4799. doi: 10.1080/00036846.2019.1597963

Blampied, C. et al. (2018). Leaving no one behind in the health and education sectors: an SDG stocktake in Ghana. London: Overseas Development Institute.

Bofah, E. A., \& Hannula, M. S. (2015). TIMSS data in an African comparative perspective: Investigating the factors influencing achievement in mathematics and their psychometric properties. Large-Scale Assessments in Education, 3(1), Article number 4.

Bofah, E. A., \& Hannula, M. S. (2017). Home resources as a measure of socioeconomic status in Ghana. Largescale Assessments in Education, 5(1), 1-15.

Broer, M., Bai Y., \& Fonseca, F. (2019). A review of the literature on socioeconomic status and educational achievement. In: Socioeconomic Inequality and Educational Outcomes. IEA Research for Education (vol 5). Springer, Cham.

Bronfenbrenner, U. (2005). Making human beings human: Bioecological perspectives on human development. Thousand Oaks, CA: Sage.

Çiftçi, K.S., \& Cin, M.F. (2018). What matters for rural teachers and communities? Educational challenges in rural Turkey. Compare: A Journal of Comparative and International Education, 48(5), 686-701,

Cochran-Smith, M., Cannady, M., McEachern, K., Mitchell, K., Piazza, P., Power, C., \& Ryan, A. (2012). Teachers' education and outcomes: Mapping the research terrain. Teachers College Record, 114(10), 1-49.

Cochran-Smith, M. \& Zeichner, K.M. (Eds.) (2005). Studying teacher education. The report of the AERA Panel on research and teacher education. Washington DC: Lawrence Erlbaum Associates, Inc.
Considine, G., \& Zappala, G. (2002). Influence of social and economic disadvantage in the academic performance of school students in Australia. Journal of Sociology, 38, 129-148.

Destin, M., Hanselman, P., Buontempo, J., Tipton, E., \&Yeager, D.S. (2019). Do student mindsets differ by socioeconomic status and explain disparities in academic Achievement in the United States? AERA Open, 5(3), 1-12.

Fan, X., \& Chen, M. (2001). Parental involvement and students' academic achievement: A meta-analysis. Educational Psychology Review, 13(1):1-22.

Fredriksen, B., \& R., Kagia, R. (2013). Attaining the 2050 vision for Africa: Breaking the human capital barrier. Global Journal of Emerging Market Economies, 5 (3), 269-328.

Ghana Statistical Service. (2012). 2010 population and housing census. Summary report of final results. Accra: Ghana Statistical Service.

Ghana Statistical Service. (2014). Ghana living standards survey round 6: poverty profile in Ghana: 2005-13. Accra: Ghana Statistical Service.

Ghana Statistical Service. (2015). Ghana poverty mapping report. Accra: Ghana Statistical Service.

Hanson, M. J., Miller, A. D., Diamond, K., Odom, S., Lieber, J., Butera, G., Horn, E., Palmer, S., \& Fleming, K. (2011). Neighborhood community risk influences on preschool children's development and school readiness. Infants \& Young Children, 24(1), 87-100.

Heck, R.H., \& Thomas, S.L. (2015). An introduction to multilevel modelling techniques. MLM and SEM approaches using Mplus (3rd ed). Routledge. Taylor and Francis.

Hill, H. C., Charalambous, C. Y., \& Chin, M. J. (2019). Teacher characteristics and student learning in mathematics: a comprehensive assessment. Education Policy, 33, 1103-1134. doi: 10.1177/0895904818755468

Hornby, G., \& Lafaele, R. (2011). Barriers to parental involvement in education: an explanatory model. Educational Review, 63(1), 37-52.

Hox, J. J., Moerbeek, M., \& van de Schoot, R. (2017). Multilevel analysis: Techniques and applications. Quantitative methodology series (3rd ed). Routledge.

Kim, S.W., Cho, H., \& Kim, L.Y. (2019). Socioeconomic status and academic outcomes in developing countries: A meta-analysis. Review of Educational Research, 20(10), 1-42. 
Lenhardt, A., Rocha Menocal, A., \& Engel, J. (2015). Ghana, the rising star: progress in political voice, health and education. London: Overseas Development Institute.

Martin, M. O., Mullis, I. V. S., Foy, P., \& Hooper, M. (2016). TIMSS 2015 international results in science. Chestnut Hill, MA: TIMSS \& PIRLS International Study Center, Boston College.

Meyer, H. \& Benavot, A. (Eds) (2013). PISA, power, and policy: The emergence of global educational governance. Symposium Books Ltd.

Ministry of Education. (2014). Ghana 2013 national education assessment technical report. Accra: Ghana.

Ministry of Education. (2015). Inclusive education policy in Ghana. Accra: MoE

Ministry of Education. (2016a). Ghana national educational assessment technical report. Accra:MoE.

Ministry of Education. (2016b). Education sector performance report. Accra: MoE.

Ministry of Education. (2018). Ghana education sector analysis. Accra: MoE.

Mullis, I.V.S., Martin, M.O., \& Loveless, T. (2016). 20 Years of TIMSS: International trends in mathematics and science achievement, curriculum, and instruction. Chestnut Hill, MA: TIMSS \& PIRLS International Study Center, Boston College.

Nyatsikor. M.K., Sosu, E.M., Mtika, P. \& Robson, D. (2020). Teacher characteristics and children's educational attainment in Ghana: do some teacher characteristics matter more for children attending disadvantaged schools? Frontiers in Education, 5(162). doi:10.3389/feduc.2020.00162

Organization for Economic Co-operation and Development. (2016). Low performing students: Why they fall behind and how to help them succeed. Paris:PISA.

Organization for Economic Co-operation and Development. (2017). Starting strong: Key OECD indicators on early childhood education and care. Paris:Organization for Economic Co-operation and Development.

Owens, A. (2018). Income segregation between school districts and inequality in students' achievement. Sociology of Education, 91(1), 1-27.

Prasertcharoensuk, T., \& Tapkhwa, N. (2016). Schools, parents, and community partnership enhancing students' learning achievement. Contemporary Educational Researches Journal, 6(1), 30-39.
Reardon, S. F. (2011). The widening academic achievement gap between the rich and the poor: New evidence and possible explanations. In R. Murnane \& G. Duncan (Eds.), Whither opportunity? Rising inequality and the uncertain life chances of low-income children. New York, NY: Russell Sage Foundation Press.

Reardon, S.F., Fahle, E.M., Kalogrides,D., Podolsky,A., Za'rate, R.C. (2019). Gender achievement gaps in U.S. School Districts. American Educational Research Journal, 56(6), 2474-2508.

Rogošić, S., \& Baranović, B. (2016). Social capital and educational achievements: Coleman vs. Bourdieu. CEPS Journal, 6(2), 81-100.

Ryan, S., Koczberski, G., Curry, G. N., \& Germis, E. (2017). Intra-household constraints on educational attainment in rural households in Papua New Guinea. Asia Pacific Viewpoint, 58, 27-40.

Tudge, J. R. H., Mokrova, I. L., Hatfield, B. E., \& Karnik, R. B. (2009). Uses and misuses of Bronfenbrenner's bioecological theory of human development. Journal of Family Theory and Review, 1(4), 198-210.

United Nations Educational Scientific Cultural Organisation. (2018). Learning at the bottom of the pyramid: Science, measurement, and policy in low income countries. International Institute for Educational Planning. UNESCO.

United Nations International Cultural Educational Fund and Centre for Democratic Development (CDD)-Ghana. (2016). District league table 2016: calling for central government to better target district support. Accra:CDD.

United Nations International Cultural Educational Fund and Centre for Democratic Development (CDD)-Ghana. (2019). District League Table II. Monitoring social development in Ghana. Accra:CDD.

United Nations. (2015). Helping governments and stakeholders make sustainable development goals a reality. New York: United Nations.

World Development Report. (2018). Learning to realize education's promise: Overview. Washinton, DC: World Bank Group.

\section{Authors}

${ }^{1}$ Maxwell Kwesi Nyatsikor (mnyatsikor@uds.edu.gh) is a Lecturer in the Faculty of Education at the University for Developmental Studies, Tamale, Ghana.

${ }^{2}$ Winston Kwame Abroampa (wkabroampa@knust.edu. $\mathrm{gh}$ ) is a Senior Lecturer in the Faculty of Educational Studies at Kwame Nkrumah University for Science and Technology, Kumasi, Ghana.

${ }^{3}$ Kweku Esia-Donkoh (ke_donkoh@yahoo.com) is a Senior Lecturer in the Faculty of Educational Studies at University of Education, Winneba, Ghana. 


\section{Supplementary Materials}

Supplemental Table 1: Fixed effect estimates for P3 sample

\begin{tabular}{|c|c|c|c|c|c|c|}
\hline \multirow{3}{*}{$\begin{array}{l}\text { Variables } \\
\text { /subject }\end{array}$} & \multicolumn{3}{|c|}{ English language } & \multicolumn{3}{|c|}{ Mathematics } \\
\hline & $\begin{array}{c}\text { Model 0 } \\
\text { Null model }\end{array}$ & $\begin{array}{c}\text { Model 1 } \\
\text { Covariates }\end{array}$ & $\begin{array}{c}\text { Model } 2 \text { Predictor } \\
\text { variable }\end{array}$ & $\begin{array}{c}\text { Model } 0 \\
\text { Null model }\end{array}$ & $\begin{array}{c}\text { Model 1 } \\
\text { Covariates }\end{array}$ & $\begin{array}{c}\text { Model } 2 \text { Predictor } \\
\text { variable }\end{array}$ \\
\hline & $\begin{array}{l}\text { Coeff. } \\
\text { (SE) }\end{array}$ & $\begin{array}{l}\text { Coeff. } \\
\text { (SE) }\end{array}$ & $\begin{array}{l}\text { Coeff. } \\
\text { (SE) }\end{array}$ & $\begin{array}{l}\text { Coeff. } \\
\text { (SE) }\end{array}$ & $\begin{array}{l}\text { Coeff. } \\
\text { (SE) }\end{array}$ & $\begin{array}{l}\text { Coefft. } \\
\text { (SE) }\end{array}$ \\
\hline Intercept & $\begin{array}{l}-.331 \\
(.273)\end{array}$ & $\begin{array}{l}3.825 \\
(.501)\end{array}$ & $\begin{array}{l}5.648 \\
(.610)\end{array}$ & $\begin{array}{l}-.134 \\
.201)\end{array}$ & $\begin{array}{l}2.753 \\
(.414) \\
\end{array}$ & $\begin{array}{l}4.038 \\
(.504) \\
\end{array}$ \\
\hline \multicolumn{7}{|c|}{ Controlled variables } \\
\hline Pupil (male) & & $\begin{array}{c}.029 \\
(.073) \\
\end{array}$ & $\begin{array}{c}.029 \\
(.073) \\
\end{array}$ & & $\begin{array}{c}.226 \\
(.068)^{* * *}\end{array}$ & $\begin{array}{c}.226 \\
(.068)^{* * * *} \\
\end{array}$ \\
\hline Pupil (age) & & $\begin{array}{c}-.156 \\
(.023)^{* * * k}\end{array}$ & $\begin{array}{c}-.156 \\
(.023)^{* k+k}\end{array}$ & & $\begin{array}{c}.073 \\
(.022)^{* * *}\end{array}$ & $\begin{array}{c}.086 \\
(.022)^{* * * *}\end{array}$ \\
\hline Class size & & $\begin{array}{c}.015 \\
(.006)^{*}\end{array}$ & $\begin{array}{c}.010 \\
(.006) \\
\end{array}$ & & $\begin{array}{c}-.004 \\
(.006) \\
\end{array}$ & $\begin{array}{c}.003 \\
(.006) \\
\end{array}$ \\
\hline Deprived type & & $\begin{array}{c}-1.289 \\
(.423)^{* *}\end{array}$ & $\begin{array}{c}.894 \\
(.404)^{*}\end{array}$ & & $\begin{array}{c}.973 \\
(.326)^{* *}\end{array}$ & $\begin{array}{c}.669 \\
(.317)^{*}\end{array}$ \\
\hline Public School & & $\begin{array}{c}-5.787 \\
(.391)^{* * k *}\end{array}$ & $\begin{array}{c}-5.722 \\
(.385)^{* * * k}\end{array}$ & & $\begin{array}{c}-4.266 \\
(.341)^{* * *}\end{array}$ & $\begin{array}{c}-4.193 \\
(.336)^{* * * *}\end{array}$ \\
\hline \multicolumn{7}{|c|}{ Predictor variable } \\
\hline $\begin{array}{l}\text { School location } \\
\text { (Rural school) }\end{array}$ & & & $\begin{array}{c}-2.085 \\
(.441)^{*-k * k} \\
\end{array}$ & & & $\begin{array}{c}-1.498 \\
(.367)^{*+4 *} \\
\end{array}$ \\
\hline \multicolumn{7}{|c|}{ Variance component } \\
\hline Pupil (\%) & 54.8 & 67.2 & 68.9 & 63.5 & 72.0 & 73.0 \\
\hline School (\%) & 29.7 & 23.8 & 24.2 & 27.6 & 23.7 & 23.8 \\
\hline District (\%) & 15.5 & 9.0 & 6.9 & 8.9 & 4.3 & 3.2 \\
\hline -2LL (deviance) & 98083 & 97168 & 97147 & 95670 & 94850 & 94834 \\
\hline $\begin{array}{l}\text { Change in } \\
\text { deviance } \\
(-2 L L)\end{array}$ & 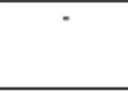 & 915 & 21 & $\cdot$ & 820 & 16 \\
\hline $\mathrm{X}^{2}(.01)$ & - & 15.09 & 16.81 & - & 15.09 & 16.81 \\
\hline df & - & 5 & 6 & - & 5 & 6 \\
\hline$p$-value & - & $8 * * 8$ & $*$ & - & $* *$ & 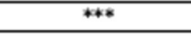 \\
\hline
\end{tabular}

Note: ${ }^{* * *} p<.0 .001 ;{ }^{* *} p<.01 ;{ }^{*} p<.05$. Coeff = coefficient; $S E=$ standard error

Supplemental Table 2: Fixed effect estimates for P6 sample

\begin{tabular}{|c|c|c|c|c|c|c|}
\hline \multirow{3}{*}{$\begin{array}{l}\text { Variable/ } \\
\text { subject }\end{array}$} & \multicolumn{3}{|c|}{ English language } & \multicolumn{3}{|c|}{ Mathematics } \\
\hline & $\begin{array}{c}\text { Model 0 } \\
\text { Null model }\end{array}$ & $\begin{array}{c}\text { Model 1 } \\
\text { Covariates }\end{array}$ & $\begin{array}{c}\text { Model } 2 \text { Predictor } \\
\text { variable }\end{array}$ & $\begin{array}{c}\text { Model 0 } \\
\text { Null model }\end{array}$ & $\begin{array}{c}\text { Model 1 } \\
\text { Covariates }\end{array}$ & $\begin{array}{c}\text { Model } 2 \text { Predictor } \\
\text { variable }\end{array}$ \\
\hline & $\begin{array}{l}\text { Coeff. } \\
\text { (SE) }\end{array}$ & $\begin{array}{l}\text { Coeff. } \\
\text { (SE) }\end{array}$ & $\begin{array}{l}\text { Coeff. } \\
\text { (SE) }\end{array}$ & $\begin{array}{l}\text { Coeff. } \\
\text { (SE) }\end{array}$ & $\begin{array}{l}\text { Coeff. } \\
\text { (SE) }\end{array}$ & $\begin{array}{l}\text { Coeff. } \\
\text { (SE) }\end{array}$ \\
\hline Intercept & $\begin{array}{r}-1.293 \\
(.373) \\
\end{array}$ & $\begin{array}{l}3.109 \\
(.721)\end{array}$ & $\begin{array}{l}6.281 \\
(.857) \\
\end{array}$ & $\begin{array}{l}-.449 \\
(.180)\end{array}$ & $\begin{array}{c}.994 \\
(.387) \\
\end{array}$ & $\begin{array}{l}2.200 \\
(.473)\end{array}$ \\
\hline \multicolumn{7}{|l|}{ Controlled variables } \\
\hline Pupil (male) & & $\begin{array}{c}.705 \\
(.100)^{* * * *}\end{array}$ & $\begin{array}{c}.704 \\
(.100)^{* * * *}\end{array}$ & & $\begin{array}{c}.818 \\
(.069)^{*+k * k}\end{array}$ & $\begin{array}{c}.819 \\
(.069)^{* * * 4}\end{array}$ \\
\hline Pupils age & & $\begin{array}{c}-.671 \\
(.037)^{* * k * k}\end{array}$ & $\begin{array}{c}-.670 \\
(.037)^{* * * *}\end{array}$ & & $\begin{array}{c}-.258 \\
(.025)^{* * * *}\end{array}$ & $\begin{array}{c}-.258 \\
(.025)^{* * * *}\end{array}$ \\
\hline Class size & & $\begin{array}{c}.052 \\
(.009)^{* * * *}\end{array}$ & $\begin{array}{c}.040 \\
(.009)^{* * * *}\end{array}$ & & $\begin{array}{c}.205 \\
(.005)^{* * * *}\end{array}$ & $\begin{array}{c}.016 \\
(.005)^{* * *}\end{array}$ \\
\hline Public school & & $\begin{array}{l}-6.346 \\
(.551) \\
\end{array}$ & $\begin{array}{c}-6.257 \\
(.532)^{* * * *} \\
\end{array}$ & & $\begin{array}{l}-2.655 \\
(.305) \\
\end{array}$ & $\begin{array}{c}-2.611 \\
(.300)^{* * * *}\end{array}$ \\
\hline Deprived district & & $\begin{array}{c}-2.156 \\
(.599)^{* * * k}\end{array}$ & $\begin{array}{c}-1.450 \\
(.569)^{*}\end{array}$ & & $\begin{array}{c}-1.046 \\
(.310)^{* k * k}\end{array}$ & $\begin{array}{c}-.759 \\
(.308)^{*}\end{array}$ \\
\hline \multicolumn{7}{|l|}{ Predictor variable } \\
\hline Rural school & & & $\begin{array}{c}-3.654 \\
(.606)^{* * * *}\end{array}$ & & & $\begin{array}{c}-1.401 \\
(.335)^{* * *}\end{array}$ \\
\hline \multicolumn{7}{|l|}{ Variance component } \\
\hline Pupil (\%) & 54.2 & 65.0 & 67.4 & 70.1 & 76.2 & 77.2 \\
\hline School (\%) & 29.1 & 24.5 & 24.0 & 20.5 & 17.9 & 17.5 \\
\hline District (\%) & 16.7 & 10.5 & 8.6 & 9.4 & 5.9 & 5.3 \\
\hline -2LL (deviance) & 94041 & 93344 & 93309 & 82956 & 82466 & 82449 \\
\hline $\begin{array}{l}\text { Change in deviance } \\
(-2 \mathrm{LL})\end{array}$ & $\cdot$ & 697 & 35 & $\cdot$ & 490 & 17 \\
\hline $\mathrm{X}^{2}(.01)$ & & 15.09 & 16.81 & & 15.09 & 16.81 \\
\hline df & - & 5 & 6 & - & 5 & 6 \\
\hline$p$-value & - & $* * *$ & $*$ & - & *** & $* * * *$ \\
\hline
\end{tabular}




\section{Supplementary Materials}

\begin{tabular}{|c|c|c|c|c|c|c|c|c|c|c|}
\hline \multirow[t]{2}{*}{$\begin{array}{l}\text { Region/ } \\
\text { Variable }\end{array}$} & Ashante & $\begin{array}{l}\text { Brong. } \\
\text { Ahafo }\end{array}$ & Central & Eastern & $\begin{array}{c}\text { Greater } \\
\text { Accra }\end{array}$ & Northern & $\begin{array}{c}\text { Upper } \\
\text { East }\end{array}$ & $\begin{array}{l}\text { Upper } \\
\text { West }\end{array}$ & Volta & Western \\
\hline & $\begin{array}{l}\text { Coeff. } \\
\text { (SE) }\end{array}$ & $\begin{array}{l}\text { Coeff. } \\
\text { (SE) }\end{array}$ & $\begin{array}{l}\text { Coeff. } \\
\text { (SE) }\end{array}$ & $\begin{array}{l}\text { Coeff. } \\
\text { (SE) }\end{array}$ & $\begin{array}{l}\text { Coeff. } \\
\text { (SE) }\end{array}$ & $\begin{array}{l}\text { Coeff. } \\
\text { (SE) }\end{array}$ & $\begin{array}{l}\text { Coeff. } \\
\text { (SE) }\end{array}$ & $\begin{array}{l}\text { Coeff. } \\
\text { (SE) }\end{array}$ & $\begin{array}{l}\text { Coeff. } \\
\text { (SE) }\end{array}$ & $\begin{array}{l}\text { Coeff. } \\
\text { (SE) }\end{array}$ \\
\hline Intercept & $\begin{array}{c}6.967 \\
(1.675)\end{array}$ & $\begin{array}{c}8.073 \\
(1.697)\end{array}$ & $\begin{array}{c}4.502 \\
(1.610)\end{array}$ & $\begin{array}{l}12.777 \\
(1.794)\end{array}$ & $\begin{array}{l}10.809 \\
(.874)\end{array}$ & $\begin{array}{c}2.181 \\
(1.950)\end{array}$ & $\begin{array}{c}4.591 \\
(1.279)\end{array}$ & $\begin{array}{c}6.843 \\
(2.927)\end{array}$ & $\begin{array}{c}6.991 \\
(1.833)\end{array}$ & $\begin{array}{c}2.954 \\
(2.498)\end{array}$ \\
\hline \multicolumn{11}{|c|}{ Pupils' characteristics } \\
\hline $\begin{array}{l}\text { Gender } \\
\text { (male) }\end{array}$ & $\begin{array}{c}-.149 \\
(.267)\end{array}$ & $\begin{array}{c}-.181 \\
(.228)\end{array}$ & $\begin{array}{c}.387 \\
(.280)\end{array}$ & $\begin{array}{c}-.015 \\
(.263)\end{array}$ & $\begin{array}{c}-.681 \\
(.254) \\
* *\end{array}$ & $\begin{array}{c}.264 \\
(.220)\end{array}$ & $\begin{array}{c}-.228 \\
(.166)\end{array}$ & $\begin{array}{c}.698 \\
(.174) \\
* * *\end{array}$ & $\begin{array}{c}.019 \\
(.251)\end{array}$ & $\begin{array}{c}.307 \\
(.255)\end{array}$ \\
\hline Age & $\begin{array}{l}-.372 \\
(.101) \\
* * *\end{array}$ & $\begin{array}{c}-.352 \\
(.087) \\
* s *\end{array}$ & $\begin{array}{c}.299 \\
(.105)\end{array}$ & $\begin{array}{l}. .572 \\
(.093) \\
* * * *\end{array}$ & $\begin{array}{l}-.402 \\
(.096) \\
* * * *\end{array}$ & $\begin{array}{c}.083 \\
(.057)\end{array}$ & $\begin{array}{c}-.027 \\
(.051)\end{array}$ & $\begin{array}{c}.118 \\
(.049)^{*}\end{array}$ & $\begin{array}{c}-.205 \\
(.072) \\
* *\end{array}$ & $\begin{array}{l}-.390 \\
(.090) \\
*: *\end{array}$ \\
\hline \multicolumn{11}{|c|}{ School characteristics } \\
\hline Class size & $\begin{array}{c}.015 \\
(.023)\end{array}$ & $\begin{array}{c}.003 \\
(.017)\end{array}$ & $\begin{array}{c}.014 \\
(.031)\end{array}$ & $\begin{array}{l}.057^{*} \\
(.024)\end{array}$ & $\begin{array}{l}.062^{* *} \\
(.023)\end{array}$ & $\begin{array}{c}.001 \\
(.020)\end{array}$ & $\begin{array}{c}-.006 \\
(.010)\end{array}$ & $\begin{array}{c}-.020 \\
.014)\end{array}$ & $\begin{array}{c}.046 \\
(.023)^{*}\end{array}$ & $\begin{array}{c}.019 \\
(.042)\end{array}$ \\
\hline $\begin{array}{l}\text { School } \\
\text { type } \\
\text { (public) }\end{array}$ & $\begin{array}{l}-5.990 \\
(.957) \\
* * *\end{array}$ & $\begin{array}{c}-4.810 \\
(1.375) \\
* *\end{array}$ & $\begin{array}{c}-3.853 \\
(1.136)\end{array}$ & $\begin{array}{c}-7.367 \\
(1.003) \\
* * * *\end{array}$ & $\begin{array}{c}-6.816 \\
(1.146) \\
* * * *\end{array}$ & $\begin{array}{c}8.330 \\
(1.371) \\
* * *\end{array}$ & $\begin{array}{l}-5.510 \\
(.913) \\
* * *\end{array}$ & $\begin{array}{c}-7.978 \\
(3.021) \\
* *\end{array}$ & $\begin{array}{c}-4.899 \\
(1.230) \\
* * *\end{array}$ & $\begin{array}{c}-3.333 \\
(1.311) \\
*\end{array}$ \\
\hline \multicolumn{11}{|c|}{ District characteristics } \\
\hline $\begin{array}{l}\text { District } \\
\text { type } \\
\text { (deprived) }\end{array}$ & $\begin{array}{l}-1.179 \\
(1.422)\end{array}$ & $\begin{array}{l}-2.020 \\
(1.028)\end{array}$ & $\cdot$ & $\begin{array}{c}.401 \\
(1.477)\end{array}$ & - & $\begin{array}{l}4.348^{*} \\
(1.857)\end{array}$ & $\begin{array}{c}2.116 \\
* * \\
(.827)\end{array}$ & $\begin{array}{l}-1.628 \\
(1.321)\end{array}$ & $\begin{array}{l}-.106 \\
(.965)\end{array}$ & $\begin{array}{c}-1.190 \\
(1.288)\end{array}$ \\
\hline $\begin{array}{l}\text { School } \\
\text { location } \\
\text { (rural) }\end{array}$ & $\begin{array}{c}-1.004 \\
(.909)\end{array}$ & $\begin{array}{c}-2.893 \\
(1.271)\end{array}$ & $\begin{array}{c}-2.093 \\
(1.192)\end{array}$ & $\begin{array}{c}-6.477 \\
(1.049) \\
* * *\end{array}$ & $\begin{array}{c}-3.846 \\
(1.127) \\
* * * *\end{array}$ & $\begin{array}{c}3.038 \\
(1.536) \\
*\end{array}$ & $\begin{array}{l}-1.968 \\
(1.014)\end{array}$ & $\begin{array}{c}-1.484 \\
(1.486)\end{array}$ & $\begin{array}{c}-2.355 \\
(1.277)\end{array}$ & $\begin{array}{c}.254 \\
(1.966)\end{array}$ \\
\hline \multicolumn{11}{|c|}{ Random part } \\
\hline Pupil & 80.8 & 75.3 & 73.9 & 83.1 & 75.3 & 70.0 & 84.8 & 71.6 & 77.7 & 59.2 \\
\hline School & 19.2 & 24.7 & 26.1 & 16.9 & 24.7 & 30.0 & 15.2 & 28.4 & 22.3 & 40.8 \\
\hline
\end{tabular}

Note: *** $p<.0 .001 ; * *<<.01 ;{ }^{*} p<.05$. Coeff $=$ coefficient; $S E=$ standard error

\begin{tabular}{|c|c|c|c|c|c|c|c|c|c|c|}
\hline $\begin{array}{l}\text { Region/ } \\
\text { Variable }\end{array}$ & Ashante & $\begin{array}{l}\text { Brong. } \\
\text { Ahafo }\end{array}$ & Central & Eastern & $\begin{array}{c}\text { Greater } \\
\text { Accra }\end{array}$ & $\begin{array}{c}\text { Norther } \\
n\end{array}$ & $\begin{array}{c}\text { Upper } \\
\text { East }\end{array}$ & $\begin{array}{c}\text { Upper } \\
\text { West }\end{array}$ & Volta & Western \\
\hline & $\begin{array}{l}\text { Ceeff. } \\
\text { (SE) }\end{array}$ & $\begin{array}{l}\text { Coeff. } \\
\text { (SE) }\end{array}$ & $\begin{array}{l}\text { Coeff. } \\
\text { (SE) }\end{array}$ & $\begin{array}{l}\text { Coeff. } \\
\text { (SE) }\end{array}$ & $\begin{array}{l}\text { Coeff. } \\
\text { (SE) }\end{array}$ & $\begin{array}{l}\text { Coeff. } \\
\text { (SE) }\end{array}$ & $\begin{array}{l}\text { Coeff. } \\
\text { (SE) }\end{array}$ & $\begin{array}{l}\text { Coeff. } \\
\text { (SE) }\end{array}$ & $\begin{array}{l}\text { Coeff. } \\
\text { (SE) }\end{array}$ & $\begin{array}{l}\text { Ceeff. } \\
\text { (SE) }\end{array}$ \\
\hline Intercept & $\begin{array}{c}3.421 \\
(1.435)\end{array}$ & $\begin{array}{c}6.128 \\
(1.657)\end{array}$ & $\begin{array}{c}4.573 \\
(1.517)\end{array}$ & $\begin{array}{c}8.694 \\
(1.671)\end{array}$ & $\begin{array}{l}7.474 \\
(.801)\end{array}$ & $\begin{array}{c}1.500 \\
(1.560)\end{array}$ & $\begin{array}{l}3.882 \\
(.984)\end{array}$ & $\begin{array}{c}2.850757 \\
(2.452)\end{array}$ & $\begin{array}{c}4.723 \\
(1.761)\end{array}$ & $\begin{array}{c}.869 \\
(1.975)\end{array}$ \\
\hline \multicolumn{11}{|c|}{ Pupils characteristics } \\
\hline $\begin{array}{l}\text { Gender } \\
\text { (male) }\end{array}$ & $\begin{array}{c}.011 \\
(.243)\end{array}$ & $\begin{array}{c}.349 \\
(.213)\end{array}$ & $\begin{array}{c}.081 \\
(.249)\end{array}$ & $\begin{array}{l}.299 \\
(.081)\end{array}$ & $\begin{array}{c}.441 \\
(.236)\end{array}$ & $\begin{array}{c}.483 \\
(.213)^{*}\end{array}$ & $\begin{array}{l}.165 \\
(.162)\end{array}$ & $\begin{array}{c}.799 \\
(.171) \\
* * *\end{array}$ & $\begin{array}{c}.367 \\
(.239)\end{array}$ & $\begin{array}{l}.413 \\
(.233)\end{array}$ \\
\hline Age & $\begin{array}{l}.079 \\
(.092)\end{array}$ & $\begin{array}{c}.073 \\
(.081)\end{array}$ & $\begin{array}{c}.097 \\
(.093)\end{array}$ & $\begin{array}{c}. .299 \\
(.081) \\
* * * \\
\end{array}$ & $\begin{array}{c}.138 \\
(.089)\end{array}$ & $\begin{array}{c}.220 \\
(.055) \\
* * * \\
\end{array}$ & $\begin{array}{c}.216 \\
(.050) \\
* * *\end{array}$ & $\begin{array}{c}.144 \\
(.048)^{* *}\end{array}$ & $\begin{array}{c}.190 \\
(.069) \\
* *\end{array}$ & $\begin{array}{c}-.212 \\
(.082)^{* *}\end{array}$ \\
\hline \multicolumn{11}{|c|}{ School characteristics } \\
\hline Class size & $\begin{array}{c}.005 \\
(.019) \\
\end{array}$ & $\begin{array}{c}.004 \\
(.017) \\
\end{array}$ & $\begin{array}{c}.015 \\
(.029) \\
\end{array}$ & $\begin{array}{c}.036 \\
(.022) \\
\end{array}$ & $\begin{array}{c}.033 \\
(.021) \\
\end{array}$ & $\begin{array}{l}.006 \\
(.016) \\
\end{array}$ & $\begin{array}{l}.009 \\
(.007)\end{array}$ & $\begin{array}{r}.019 \\
(.012) \\
\end{array}$ & $\begin{array}{c}.035 \\
(.022)\end{array}$ & $\begin{array}{l}.019 \\
(.033) \\
\end{array}$ \\
\hline $\begin{array}{l}\text { School } \\
\text { type } \\
\text { (public) }\end{array}$ & $\begin{array}{c}-3.065 \\
(.821) \\
* * *\end{array}$ & $\begin{array}{c}-3.290 \\
(1.342) \\
* \\
\end{array}$ & $\begin{array}{c}-4.333 \\
(1.068) \\
* * *\end{array}$ & $\begin{array}{c}-6.452 \\
(.936) \\
* * *\end{array}$ & $\begin{array}{c}-4.667 \\
(1.050) \\
* * * \\
\end{array}$ & $\begin{array}{c}-6.271 \\
(1.092) \\
* * * \\
\end{array}$ & $\begin{array}{c}-3.670 \\
(.707) \\
* * * \\
\end{array}$ & $\begin{array}{c}-3.602 \\
(2.533)\end{array}$ & $\begin{array}{c}-3.940 \\
(1.182) \\
* *\end{array}$ & $\begin{array}{r}-2.045 \\
(1.040)\end{array}$ \\
\hline \multicolumn{11}{|c|}{ District characteristics } \\
\hline $\begin{array}{l}\text { District } \\
\text { type } \\
\text { (deprived) }\end{array}$ & $\begin{array}{c}.309 \\
(1.219)\end{array}$ & $\begin{array}{c}-2.074 \\
(1.004) \\
*\end{array}$ & - & $\begin{array}{c}2.495 \\
(1.378)\end{array}$ & - & $\begin{array}{c}2.080 \\
(1.481)\end{array}$ & $\begin{array}{c}1.809 \\
(.632) \\
* *\end{array}$ & $\begin{array}{c}-.736 \\
(1.103)\end{array}$ & $\begin{array}{c}-.100 \\
(.927)\end{array}$ & $\begin{array}{c}.318 \\
(1.020)\end{array}$ \\
\hline $\begin{array}{l}\text { School } \\
\text { location } \\
\text { (rural) }\end{array}$ & $\begin{array}{l}.348 \\
(.778)\end{array}$ & $\begin{array}{l}-2.259 \\
(1.241)\end{array}$ & $\begin{array}{l}-1.838 \\
(1.124)\end{array}$ & $\begin{array}{c}-5.486 \\
(.978) \\
* * * \\
\end{array}$ & $\begin{array}{c}-2.908 \\
(1.031) \\
* *\end{array}$ & $\begin{array}{c}2.219 \\
(1.229)\end{array}$ & $\begin{array}{c}-2.279 \\
(.779) \\
* *\end{array}$ & $\begin{array}{l}-1.191 \\
(1.240)\end{array}$ & $\begin{array}{c}.968 \\
(1.227)\end{array}$ & $\begin{array}{c}-.481 \\
(1.555)\end{array}$ \\
\hline \multicolumn{11}{|l|}{ Random } \\
\hline Pupil & 82.9 & 73.4 & 71.4 & 80.8 & 75.2 & 78.6 & 90.8 & 78.1 & 77.2 & 67.0 \\
\hline School & 17.1 & 26.6 & 28.6 & 19.2 & 24.8 & 21.4 & 9.2 & 21.9 & 22.8 & 33.0 \\
\hline
\end{tabular}

Note: ${ }^{* * *} p<.0 .001 ;{ }^{* *} p<.01 ;{ }^{*} p<.05$. Coeff $=$ coefficient; $S E=$ standard error 


\section{Supplementary Materials}

\begin{tabular}{|c|c|c|c|c|c|c|c|c|c|c|}
\hline $\begin{array}{l}\text { Region/ } \\
\text { Variable }\end{array}$ & Ashante & $\begin{array}{l}\text { Brong } \\
\text { Ahafo }\end{array}$ & Central & Eastern & $\begin{array}{c}\text { Greater } \\
\text { Accra }\end{array}$ & Northern & $\begin{array}{c}\text { Upper } \\
\text { East }\end{array}$ & $\begin{array}{l}\text { Upper } \\
\text { West }\end{array}$ & Volta & Western \\
\hline & $\begin{array}{l}\text { Coeff. } \\
\text { (SE) }\end{array}$ & $\begin{array}{l}\text { Ceeff. } \\
\text { (SE) }\end{array}$ & $\begin{array}{l}\text { Coeff. } \\
\text { (SE) }\end{array}$ & $\begin{array}{l}\text { Coeff. } \\
\text { (SE) }\end{array}$ & $\begin{array}{l}\text { Coeff. } \\
\text { (SE) }\end{array}$ & $\begin{array}{l}\text { Coeff. } \\
\text { (SE) }\end{array}$ & $\begin{array}{l}\text { Ceeff. } \\
\text { (SE) }\end{array}$ & $\begin{array}{l}\text { Ceeff. } \\
\text { (SE) }\end{array}$ & $\begin{array}{l}\text { Coeff. } \\
\text { (SE) }\end{array}$ & $\begin{array}{l}\text { Coeff. } \\
\text { (SE) }\end{array}$ \\
\hline Intercept & $\begin{array}{c}8.713 \\
(3.016) \\
\end{array}$ & $\begin{array}{c}7.567 \\
(2.048)\end{array}$ & $\begin{array}{c}5.364 \\
(2.069) \\
\end{array}$ & $\begin{array}{l}11.029 \\
(2.274) \\
\end{array}$ & $\begin{array}{l}10.586 \\
(.772) \\
\end{array}$ & $\begin{array}{c}4.080 \\
(2.679)\end{array}$ & $\begin{array}{c}7.245 \\
(1.897) \\
\end{array}$ & $\begin{array}{c}2.904 \\
(4.538) \\
\end{array}$ & $\begin{array}{c}8.672 \\
(2.321) \\
\end{array}$ & $\begin{array}{c}3.494 \\
(3.379) \\
\end{array}$ \\
\hline \multicolumn{11}{|c|}{ Pupils' characteristics } \\
\hline $\begin{array}{l}\text { Gender } \\
\text { (male) }\end{array}$ & $\begin{array}{l}1.001 \\
(.356) \\
* *\end{array}$ & $\begin{array}{c}1.100 \\
(.317) \\
* * *\end{array}$ & $\begin{array}{c}.750 \\
(.366)^{*}\end{array}$ & $\begin{array}{c}.066 \\
(.324)\end{array}$ & $\begin{array}{c}.108 \\
(.292)\end{array}$ & $\begin{array}{c}.747 \\
(.285)^{* *}\end{array}$ & $\begin{array}{c}.623 \\
(.261) \\
*\end{array}$ & $\begin{array}{c}.999 \\
(.280)\end{array}$ & $\begin{array}{c}1.142 \\
(.345) \\
* * *\end{array}$ & $\begin{array}{c}.308 \\
(.372)\end{array}$ \\
\hline Age & $\begin{array}{l}-1.281 \\
(.157) \\
* * *\end{array}$ & $\begin{array}{c}-.956 \\
(.129) \\
* * *\end{array}$ & $\begin{array}{l}-1.351 \\
(.161) \\
* * *\end{array}$ & $\begin{array}{c}-1.278 \\
* * * \\
(.135) \\
* * *\end{array}$ & $\begin{array}{l}-1.232 \\
(.130) \\
* * *\end{array}$ & $\begin{array}{l}-.064 \\
(.079)\end{array}$ & $\begin{array}{l}-.304 \\
(.090) \\
* * *\end{array}$ & $\begin{array}{l}-.224 \\
(.091) \\
* *\end{array}$ & $\begin{array}{c}-.996 \\
(.116) \\
* * *\end{array}$ & $\begin{array}{l}-.946 \\
(.151) \\
* * *\end{array}$ \\
\hline \multicolumn{11}{|c|}{ School characteristic } \\
\hline Clas & $\begin{array}{c}.065 \\
(.036)\end{array}$ & $\begin{array}{c}.054 \\
(.021) \\
* *\end{array}$ & $\begin{array}{l}.028 \\
(.039)\end{array}$ & $\begin{array}{c}.125 \\
(.027) \\
* * * *\end{array}$ & $\begin{array}{c}.087 \\
(.020) \\
* * *\end{array}$ & $\begin{array}{c}.028 \\
(.020)\end{array}$ & $\begin{array}{l}.024 \\
(.014)\end{array}$ & $\begin{array}{l}.007 \\
(.022)\end{array}$ & $\begin{array}{c}.085 \\
(.028) \\
* *\end{array}$ & $\begin{array}{c}.063 \\
(.056)\end{array}$ \\
\hline $\begin{array}{l}\text { School } \\
\text { type } \\
\text { (public) }\end{array}$ & $\begin{array}{c}-6.529 \\
(1.594) \\
* * * \\
\end{array}$ & $\begin{array}{c}-5.225 \\
(1.680) \\
* *\end{array}$ & $\begin{array}{c}-5.777 \\
(1.587) \\
* * *\end{array}$ & $\begin{array}{c}-8.568 \\
(1.282) \\
* * *\end{array}$ & $\begin{array}{c}-3.491 \\
(.975) \\
* * * \\
\end{array}$ & $\begin{array}{c}-10.453 \\
(2.000) \\
* * *\end{array}$ & $\begin{array}{c}-8.853 \\
(1.496) \\
* * *\end{array}$ & $\begin{array}{l}-1.038 \\
(4.680)\end{array}$ & $\begin{array}{c}-5.278 \\
(1.533) \\
* * *\end{array}$ & $\begin{array}{c}-4.666 \\
(1.753) \\
* *\end{array}$ \\
\hline \multicolumn{11}{|c|}{ District characteristics } \\
\hline $\begin{array}{l}\text { District } \\
\text { type } \\
\text { (deprived) }\end{array}$ & $\begin{array}{l}-3.507 \\
(2.536)\end{array}$ & $\begin{array}{l}-1.897 \\
(1.256)\end{array}$ & - & $\begin{array}{c}5.500 \\
(1.883) \\
* *\end{array}$ & - & $\begin{array}{c}3.844 \\
(2.193)\end{array}$ & $\begin{array}{c}-2.038 \\
(.809) \\
* *\end{array}$ & $\begin{array}{c}.387 \\
(2.033)\end{array}$ & $\begin{array}{c}1.593 \\
(1.245)\end{array}$ & $\begin{array}{c}-.271 \\
(1.782)\end{array}$ \\
\hline $\begin{array}{l}\text { School } \\
\text { location } \\
\text { (rural) }\end{array}$ & $\begin{array}{l}-1.376 \\
(1.531)\end{array}$ & $\begin{array}{c}-4.474 \\
(1.501) \\
* *\end{array}$ & $\begin{array}{c}-4.544 \\
(1.606) \\
* *\end{array}$ & $\begin{array}{c}-8.038 \\
(1.353) \\
* * *\end{array}$ & $\begin{array}{c}-2.769 \\
(1.054) \\
* *\end{array}$ & $\begin{array}{c}.963 \\
(1.667)\end{array}$ & $\begin{array}{l}-2.970^{*} \\
(1.424)\end{array}$ & $\begin{array}{c}-5.952 \\
(2.322) \\
* *\end{array}$ & $\begin{array}{c}-4.112 \\
(1.579) \\
* *\end{array}$ & $\begin{array}{c}-.989 \\
(2.557)\end{array}$ \\
\hline \multicolumn{11}{|l|}{ Random $_{f}$} \\
\hline Pupil & 70.9 & 78.2 & 73.1 & 80.5 & 84.1 & 80.7 & 85.5 & 69.8 & 79.7 & 61.5 \\
\hline School & 29.1 & 21.8 & 26.9 & 19.5 & 15.9 & 19.3 & 15.5 & 30.2 & 20.3 & 38.5 \\
\hline
\end{tabular}

Note: ${ }^{* * *} p<.0 .001 ; * * p<.01 ;{ }^{*} p<.05$. Coeff $=$ coefficient; $S E=$ standard error

\begin{tabular}{|c|c|c|c|c|c|c|c|c|c|c|}
\hline \multirow[t]{2}{*}{$\begin{array}{l}\text { Region// } \\
\text { Variable }\end{array}$} & Ashante. & $\begin{array}{l}\text { Brong. } \\
\text { Ahafo }\end{array}$ & Central & Eastern & $\begin{array}{c}\text { Greater } \\
\text { Accra }\end{array}$ & Northern & $\begin{array}{c}\text { Upper } \\
\text { East }\end{array}$ & $\begin{array}{c}\text { Upper } \\
\text { West }\end{array}$ & Volta & Western \\
\hline & $\begin{array}{l}\text { Coeff. } \\
\text { (SE) }\end{array}$ & $\begin{array}{l}\text { Coeff. } \\
\text { (SE) }\end{array}$ & $\begin{array}{l}\text { Coeff. } \\
\text { (SE) }\end{array}$ & $\begin{array}{l}\text { Coeff. } \\
\text { (SE) }\end{array}$ & $\begin{array}{l}\text { Coeff. } \\
\text { (SE) }\end{array}$ & $\begin{array}{l}\text { Coeff. } \\
\text { (SE) }\end{array}$ & $\begin{array}{l}\text { Coeff. } \\
\text { (SE) }\end{array}$ & $\begin{array}{l}\text { Coeff. } \\
\text { (SE) }\end{array}$ & $\begin{array}{l}\text { Coeff. } \\
\text { (SE) }\end{array}$ & $\begin{array}{l}\text { Coeff. } \\
\text { (SE) }\end{array}$ \\
\hline Intercept & $\begin{array}{c}1.823 \\
(1.616) \\
\end{array}$ & $\begin{array}{c}2.214 \\
(1.229) \\
\end{array}$ & $\begin{array}{c}1.704 \\
(1.248) \\
\end{array}$ & $\begin{array}{c}5.005 \\
(1.178) \\
\end{array}$ & $\begin{array}{l}4.292 \\
(.591) \\
\end{array}$ & $\begin{array}{c}1.135 \\
(1.930) \\
\end{array}$ & $\begin{array}{c}3.936 \\
(1.086) \\
\end{array}$ & $\begin{array}{c}844 \\
(2.465) \\
\end{array}$ & $\begin{array}{c}3.045 \\
(1.224) \\
\end{array}$ & $\begin{array}{c}.616 \\
(1.934) \\
\end{array}$ \\
\hline \multicolumn{11}{|c|}{ Pupils' characteristics } \\
\hline $\begin{array}{l}\text { Gender } \\
\text { (male) }\end{array}$ & $\begin{array}{l}.490^{*} \\
(.239)\end{array}$ & $\begin{array}{c}1.684 \\
(.224) \\
* * *\end{array}$ & $\begin{array}{c}.772 \\
(.236) \\
* * *\end{array}$ & $\begin{array}{c}.382 \\
(.234)\end{array}$ & $\begin{array}{c}.514 \\
(.226)^{*}\end{array}$ & $\begin{array}{c}.839 \\
(.194)\end{array}$ & $\begin{array}{c}.472 \\
(.177) \\
* *\end{array}$ & $\begin{array}{c}.941 \\
(.185) \\
* * *\end{array}$ & $\begin{array}{c}1.205 \\
(.227) \\
* * *\end{array}$ & $\begin{array}{c}.874 \\
(.272) \\
* * * * \\
\end{array}$ \\
\hline Age & $\begin{array}{l}-.492 \\
(.105) \\
* \approx *\end{array}$ & $\begin{array}{l}-.327 \\
(.091) \\
* * *\end{array}$ & $\begin{array}{c}-.671 \\
(.104) \\
* * * *\end{array}$ & $\begin{array}{l}-.576 \\
(.097) \\
* * *\end{array}$ & $\begin{array}{l}. .574 \\
(.100) \\
* * *\end{array}$ & $\begin{array}{l}.097 \\
(.054)\end{array}$ & $\begin{array}{c}-.136 \\
(.060) \\
*\end{array}$ & $\begin{array}{c}-.120 \\
(.060) \\
*\end{array}$ & $\begin{array}{l}-.300 \\
(.076) \\
* * *\end{array}$ & $\begin{array}{l}-.356 \\
(.111) \\
* * * *\end{array}$ \\
\hline \multicolumn{11}{|c|}{ School characteristics } \\
\hline Class size & $\begin{array}{c}.009 \\
(.019)\end{array}$ & $\begin{array}{c}.024 \\
(.012)\end{array}$ & $\begin{array}{c}.024 \\
(.024)\end{array}$ & $\begin{array}{c}.045 \\
(.014) \\
* *\end{array}$ & $\begin{array}{l}.056 \\
(.016) \\
* * *\end{array}$ & $\begin{array}{l}.020 \\
(.014)\end{array}$ & $\begin{array}{l}.011 \\
(.008)\end{array}$ & $\begin{array}{c}-.007 \\
(.012)\end{array}$ & $\begin{array}{c}.040 \\
(.015) \\
* *\end{array}$ & $\begin{array}{c}-.003 \\
(.032)\end{array}$ \\
\hline $\begin{array}{l}\text { School } \\
\text { type } \\
\text { (public) }\end{array}$ & $\begin{array}{l}-1.604 \\
(.857)\end{array}$ & $\begin{array}{c}-.991 \\
(1.006)\end{array}$ & $\begin{array}{l}-2.199 \\
(.960)^{*}\end{array}$ & $\begin{array}{c}-4.388 \\
(.666) \\
* * *\end{array}$ & $\begin{array}{c}-2.554 \\
(.745) \\
* * *\end{array}$ & $\begin{array}{c}-4.100 \\
(1.441)\end{array}$ & $\begin{array}{c}-5.017 \\
(.866) \\
* * *\end{array}$ & $\begin{array}{c}-189 \\
(2.537)\end{array}$ & $\begin{array}{c}-1.665 \\
(.799) \\
*\end{array}$ & $\begin{array}{l}-1.019 \\
(1.012)\end{array}$ \\
\hline \multicolumn{11}{|c|}{ District characteristics } \\
\hline $\begin{array}{l}\text { District } \\
\text { type } \\
\text { (deprived) }\end{array}$ & $\begin{array}{c}-.369 \\
(1.357)\end{array}$ & $\begin{array}{l}-1.190 \\
(.755)\end{array}$ & - & $\begin{array}{c}2.365 \\
(.964) \\
*\end{array}$ & - & $\begin{array}{c}.414 \\
(1.584)\end{array}$ & $\begin{array}{c}2.124 \\
(.667) \\
* * \\
\end{array}$ & $\begin{array}{c}-.286 \\
(1.099)\end{array}$ & $\begin{array}{l}1.100 \\
(.655)\end{array}$ & $\begin{array}{c}.131 \\
(1.027)\end{array}$ \\
\hline $\begin{array}{l}\text { School } \\
\text { location } \\
\text { (rural) }\end{array}$ & $\begin{array}{l}.243 \\
(.817)\end{array}$ & $\begin{array}{c}-1.962 \\
(.897) \\
*\end{array}$ & $\begin{array}{c}-2.321 \\
(.966) \\
*\end{array}$ & $\begin{array}{c}-3.534 \\
(.699 \Omega \\
* * * \\
\end{array}$ & $\begin{array}{l}. .220 \\
(.806)\end{array}$ & $\begin{array}{c}.270 \\
(1.201)\end{array}$ & $\begin{array}{l}-1.036 \\
(.813)\end{array}$ & \begin{tabular}{|c|}
-2.335 \\
$(1.246)$
\end{tabular} & $\begin{array}{c}-2.623 \\
(.831) \\
* *\end{array}$ & $\begin{array}{c}.130 \\
(1.464)\end{array}$ \\
\hline \multicolumn{11}{|c|}{ Random part } \\
\hline Pupil & 80.4 & 84.2 & 76.0 & 90.5 & 84.4 & 78.2 & 89.9 & 78.2 & 87.2 & 73.2 \\
\hline School & 19.6 & 15.8 & 24.0 & 9.5 & 15.6 & 21.8 & 10.1 & 21.8 & 12.8 & 26.8 \\
\hline
\end{tabular}

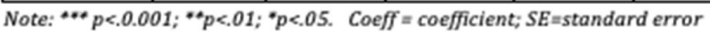

